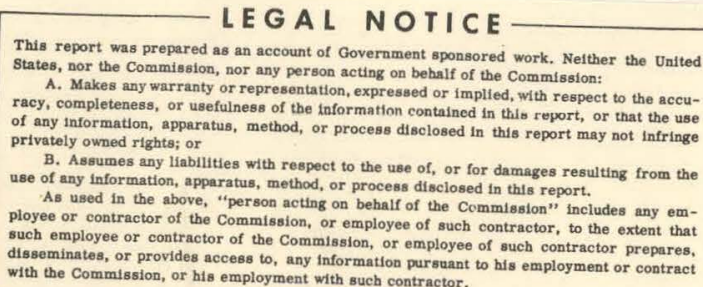

B. Assumes any liabllittes with respect to the use of, or for damages resulting from the As used in the above, "person acting or process disclosed in this report.

ployee or contractor of the Commission, or employee of Commission" includes any emsuch employee or contractor of the Commission, or employee of suctor, to the extent that disseminates, or provides access to, any informatton pursuant to his employment prepares, with the Commission, or his employment with such contraction

DUQUESNE LIGHT COMPANY

SHIPPINGPORT ATOMIC POWER STATION

TEST EVALUATION

DLCS 3050123

RADIATION SURVEY OF THE REACTOR VESSEL HEAD

Core 1 Seed 3

\section{Test Performance}

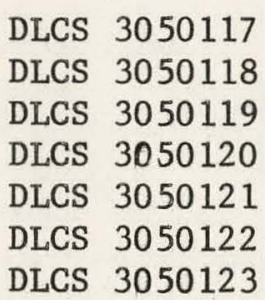

\section{Date}

March 14, 1962

Apri 1 14, 1962

Ju1y 24, 1962

July 26, 1962

September 27, 1962

November 23, 1962

November 24, 1962
Facsimile Price $\$$

Microfilm Price \$

$2.6 C$

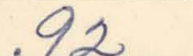

Available from the Office of Technical Services Department of Commerce Washington 25, D. C.
First Issue, February 28, 1963 


\section{DISCLAIMER}

This report was prepared as an account of work sponsored by an agency of the United States Government. Neither the United States Government nor any agency Thereof, nor any of their employees, makes any warranty, express or implied, or assumes any legal liability or responsibility for the accuracy, completeness, or usefulness of any information, apparatus, product, or process disclosed, or represents that its use would not infringe privately owned rights. Reference herein to any specific commercial product, process, or service by trade name, trademark, manufacturer, or otherwise does not necessarily constitute or imply its endorsement, recommendation, or favoring by the United States Government or any agency thereof. The views and opinions of authors expressed herein do not necessarily state or reflect those of the United States Government or any agency thereof. 


\section{DISCLAIMER}

Portions of this document may be illegible in electronic image products. Images are produced from the best available original document. 
TEST. EVALUATION

DLCS 3050117 through DLCS 3050123

RADIATION SURVEY OF THE REACTOR VESSEL HEAD

CORE $1 \cdot$ SEED 3

\section{Introduction}

DLCS 30501, Radiation Survey of the Reactor Vessel Head, was performed a total of seven times during Core 1 , Seed 3 operation. The initial Seed 3 performance: of this test was made at approximately $3300 \cdot \mathrm{EFPH}$ and the last Seed 3 performance was made at 7329. EFPH, following the performance of DLCS 14804, Control Rod Drive..Exercise.Test: This document evaluates the information obtained during these seven performances of DLCS 30501.

\section{Purpose}

The purpose of these tests was to make a detailed radiation survey of the reactor vessel head and obtain data to determine the magnitude of the radiation in the vicinity of the reactor vessel head after extended power operation and how this magnitude is effected by normal rod motion and scrams.

\section{Conclusions}

Evaluation of the data obtained during the seven Core 1 , Seed 3 performances of this test indicates:

1. The performance of DLCS 14804, Contro1.Rod Drive Mechanism Exercise Test, lowered the radiation levels of the rod drive mechanisms at elevations of one, two and three feet above the reactor vessel head.

2. The performance of DLCS 14804, Control Rod Drive Mechanism Exercise Test, raised the radiation levels of the rod drive mechanisms at elevations of four, flve and six feet above the reactor vessel head.

3. The radiation levels near the rod drive mechanisms of the control rods being used to control the reactor show no definite trend to be higher or lower than the average of all the mechanisms.

4. The change in the sensitivity of a Cutie. Pie survey meter brought about by a change in the ambient temperature of the meter is a function of the individual meter. The sensitivity of some meters will increase when their temperature is increased but other meters will decrease in sensitivity as their temperature is increased. 
TEST :PROCEDURE DLCS 3050117 through .DLCS 3050123

RADIATION SURVEY OF THE REACTOR VESSEL HEAD

\section{Genera1. Test Method}

With the reactor shutdown and the reactor coolant pressure reduced to $1200 \mathrm{psig}$, the radiation levels of the control rod drive mechanisms, the refueling ports, the Flow Measurement Instrumentation (FMI) enclosures, the Seed Metal Instrumentation (SMI) thermacouple bosses and the Failed Element Detection and Location (FEDAL) multipor $\ddot{t}$ alve were measured using Cutie Pie survey meters.

The rod drive mechanisms were surveyed from inside the mechanism cage for the first six feet at one foot intervals. The mechanisms were also briefiy scanned at the one, three and six foot levels from outside the mechanism cage.

The SMI bosses, the FMI enclosures and the refueling ports were surveyed at the top, middle and bottom: The FEDAL multiport valve was surveyed at several

selected points.

The surface temperature of the Cutie Pie survey meter was measured immediately prior to and after the survey. After each of these temperature measurements the Cutie Pie was placed on, a selected fuel port and the radiation level was recorded. The change in the temperature of the Cutie Pie and the difference in the recorded radiation level for the same fuel port aided in determining the effects of temperature changes on the sensitivity of the Cutie Pie survey meter.

$\underline{\text { Results }}$

DLCS 3050117

This test was performed on March 14, 1962, (3274.EFPH, Core 1, Seed 3) in accordance with the seventh issue of the approved test procedure. The reactor was shutdown on March 12, 1962, in accordance with DLCS 34402, Rapid Station Shutdown. After the completion of DLCS 15601, Xenon Transient Test, the radiation survey of the reactor vessel head was performed. The average radiation level of the lower three feet of the rod drive mechanisms was $529 \mathrm{mr} / \mathrm{hr}$ and the average radiation level of the four, five and six foot elevations was $216 \mathrm{mr} / \mathrm{hr}$ (Refer to Table III). The rather high radiation levels at the higher elevations of the rod drive mechanisms can probably be attributed to the three scrams which occurred within a short period of time preceding the survey (See Table I).

The radiation levels of refueling ports, the FMI enclosure assemblies, the SMI bosses and the multiport valve appeared to be slightly higher than the levels which existed at the end of Seed 2, life, with the exception of the bottom of the fuel ports which averaged only $66 \mathrm{mr} / \mathrm{hr}$ in this test performance. This was approximately a factor of three less than the average radiation level of these points at the end of Seed 2 life. 
TEST PROCEDURE DLCS 3050117 through DLCS 3050123

RADIATION SURVEY OF THE REACTOR VESSEL HEAD

\section{DLCS 3050118}

This test was performed on Apri1.14, 1962 (3429 EFPH, Core 1, Seed 3) in accordance with the eighth issue of the approved test procedure.

The combined average radiation level of the lower three feet of the rod drive mechantsms was $590 \mathrm{mr} / \mathrm{hr}$. The average radiation level at the two foot elevation of the rod drive mechanisms was only $420 \mathrm{mr} / \mathrm{hr}$ which was less than the average radiation level at this elevation during the previous survey. The average radiation levels at the four, five and six foot elevations of the rod drive mechanisms also decreased.

There were three scrams and a number of thermal cycles between this test performance and the preceding one which could possibly account for some of the changes in radiation levels observed between the two performances.

With the exception of the average radiation level at the top of the refueling ports, the average radiation levels of the other reactor vessel head components increased (Refer to Table.V). The radiation survey of the SMI bosses was inadvertently omitted. The increase in the radiation levels of the reactor vessel head components after several thermal cycles and on 1 y 155 EFPH of operation between the two surveys indicates that thermal cycles may not have a pronounced effect on the crud which adheres to these components.

Unfortunately, the Cutie Pie meter which was used to survey the .components" was not in exact calibration; however, a check of the calibration of the meters following the survey indicated that the meter was within $10 \%$ at al1 points checked.

\section{DLCS 3050119}

This test was performed on July 24, 1962 (5454 EFPH, Core 1, Seed 3) in accordance with the eighth issue of the approved test procedure. The Station was shutown on July 23, 1962 and the radiation survey of the reactor vessel head was made after the completion of DLCS 15601, Xenon Transient Test.

The average radiation levels at the lower three feet of the rod drive mechanisms were $695 \mathrm{mr} / \mathrm{hr}$. with the average radiation level at the one foot elevation-being $1086 \mathrm{mr} / \mathrm{hr}$.

In contrast to the high radiation levels present at the lower elevations, the four, five and six foot elevations had very low radiation levels, the combined average of which was $120 \mathrm{mr} / \mathrm{hr}$ 。

The radiation levels of the refueling ports were approximately the same as the levels observed during the previous survey and the radiation levels pf the. FMI enclosures decreased slightly. The radiation levels of the multipor valve decreased at all points except the bottom of the valve body which increased from $275 \mathrm{mr} / \mathrm{hr}$ to $400 \mathrm{mr} / \mathrm{hr}$. The average radiation level at the top of the SMI bosses was about the same as the level determined for DLCS 3050117 , but the average levels at the middle and bottom increased to $300 \mathrm{mr} / \mathrm{hr}$ and $592 \mathrm{mr} / \mathrm{hr}$ respectively. 
During this test the Cutie Pie survey meter which was being used to measure the radiation levels inside the mechanism cage failed. The meter was indicating very high radiation levels and, when placed in a $450 \mathrm{mr} / \mathrm{hr}$ radiation field it indicated $700 \mathrm{mr} / \mathrm{hr}$. The surface temperature of the meter was measured as soon as the failure was noticed and was found to be $140 \mathrm{~F}$. A second Cutie Pie survey meter was used to continue the survey inside the twechanism cage. The surface temperature of this second meter at the end of the survey was " $165 \mathrm{~F}$.

Due to the failure of the survey meter the recorded radiation levels of eight rod drive mechanisms at the one, two and three foot elevations were considered to be unreliable. These levels ranged from $1000 \mathrm{mr} / \mathrm{hr}$ at the three foot elevation to $2200 \mathrm{mr} / \mathrm{hr}$ at the one foot elevation.

\section{DLCS 3050120}

This test was performed on July 26, 1962 (5454 EFPH, Core 1, Seed 3) following the completion of DLCS, 14804, Control Rod Exercise Test. During DLCS 14804, the control rods were withdrawn to 69 inches and then inserted to one inch. This was done a second time and then the control rods were scrammed twice from a height of 69 inches.

The average radiation levels at the one and two foot elevations of the rod drive mechanisms during this test was $551 \mathrm{mr} / \mathrm{hr}$ and $343 \mathrm{mr} / \mathrm{hr}$, respectively. The combined average radiation level at the lower three feet of the rod drive mechaniems was on $1 \mathrm{y} 416 \mathrm{mr} / \mathrm{hr}$ which is a reduction of approximately 40 percent from the average radiation level prior to the rod exercise.

The rod exercise was not effective in reducing the radiation levels which existed at the three, four, five and six foot elevations of the rod drive mechanisms. The average radiation level at the three foot elevation was decreased from 372 $\mathrm{mr} / \mathrm{hr}$ to $366 \mathrm{mr} / \mathrm{hr}$ by the rod exercise but the combined average radiation level at the upper three feet of the rod drive mechanisms was increased from $120 \mathrm{mr} / \mathrm{hr}$ to $226 \mathrm{mr} / \mathrm{hr}$.

The average radiation levels at the bottom of the refueling ports and the FMI enclosures decreased after the rod exercise but at the top and middle the average radiation levels either increased or exhibited no change. The radiation levels of the SMI bosses decreased from $60 \%$ to $80 \%$ of their values prior to the rod exercise. The radiation levels of the multiport valve increased at al1 points except the by pass line which decreased from $450 \mathrm{mr} / \mathrm{hr}$ to $375 \mathrm{mr} / \mathrm{hr}$. This decrease in the radiation level in the vicinity of the by pass line may have been due to a different placement of the Cutie Pie survey meter.

\section{DLCS 3050121}

This test was performed on September 27, 1962 (6935 EFPH, Core.1, Seed 3). following the completion of DLCS 15601, Xenon Transient Test. 
The combined average radiation level at the lower three feet of the rod drive mechanisms was $502 \mathrm{mr} / \mathrm{hr}$ which is higher than the average value obtained following the rod exercise, but well be low the average for DLCS 3050119 . The combined average radiation level at the upper three feet of the rod drive mechanisms was $140 \mathrm{mr} / \mathrm{hr}$ as opposed to the value of $226 \mathrm{mr} / \mathrm{hr}$ established during the preceding survey.

The average radiation levels at the top of the refueling ports, and the top and middle of the FMI enclosures decreased slightly or did not change. At their other points the average radiation level increased. The average radiation levels of the SMI bosses increased $15 \%$ to $60 \%$. The radiation level of the by-pass line on the multiport valve increased to $680 \mathrm{mr} / \mathrm{hr}$ but at the top of the stator water jacket and the top of the valve body the radiation levels decreased to $52 \mathrm{mr} / \mathrm{hr}$ and $100 \mathrm{mr} / \mathrm{hr}$, respectively.

The calibration of the Cutie Pie survey meter used on the outside of the mechanism cage was very poor prior to the survey. For this reason all of the readings taken with this meter were reviewed and where necessary the readings were corrected. The values presented in this evaluation do not incorporate corrections for meter calibration with the exception of the above mentioned readings.

\section{DLCS 3050122}

This test was performed on November 23, 1962, in accordance with the eighth issue of the approved test procedure dated April 11, 1962. The Station was shutdown at .0731 hours on November 23,.1962 (7329 EFPH, Core 1,. Seed 3). The shutdown terminated the reduced power operation of seed 3 and marked the end of Seed 3 life.

The average radiation level at the one foot elevation of the rod drive mechanisms was $1044 \mathrm{mr} / \mathrm{hr}$. The maximum radiation level at the one foot elevation was 1350 . $\mathrm{mr} / \mathrm{hr}$ on mechanism $\mathrm{K}-11$. The averages of the radiation levels at the two and three foot elevations were comparatively low and the combined average radiation level of the lower three feet of the rod drive mechanisms was only $597 \mathrm{mr} / \mathrm{hr}$.

The combined average radiation level at the four, five and six. foot elevations was $117 \mathrm{mr} / \mathrm{hr}$. which is the lowest combined average radiation level obtained for these elevations during all.Seed 3 performances of this test.

. With the exception of the bottom of the FMI enclosures which increased from $123 \mathrm{mr} / \mathrm{hr}$.to $188 \mathrm{mr} / \mathrm{hr}$, the average radiation levels of the refueling ports and the FMI enclosures had decreased since the previous performance of this test. The average radiation levels of the SMI bosses increased by $40 \%$ or more since the previous test performance. The radiation levels of the multiport valve! were approximately the same as the levels which existed during the first survey of the mulitport valve during seed 3 .

While the combined average radiation level at the lower three feet of the rod drive mechanisms were sufficiently low (less than $700 \mathrm{mr} / \mathrm{hr}$ ) so as not to require the performance of DLCS 14804, Control. Rod Exercise Test, the test was nevertheless scheduled since refueling was about to begin. 
TEST PROCEDURE .DLCS 3050117 through DLCS 3050123

RADIATION SURVEY OF THE REACTOR VESSEL HEAD

\section{DLCS 3050123}

This test was performed on November 24,1962 , in accordance with the eighth issue of the approved test procedure, following the performance of DLCS 14804, Control Rod Exercise Test.

The average radiation level at the one foot elevation of the rod drive mechanisms was $544 \mathrm{mr} / \mathrm{hr}$ which was a reduction of $48 \%$ from the average radiation level which existed prior to the rod exercise. The combined average radiation level at the lower three feet of the rod drive mechanisms was reducëd from $597 \mathrm{mr} / \mathrm{hr}$ to 379 $\mathrm{mr} / \mathrm{hr}$.

Although the radiation levels were effectively reduced at the lower elevations, the radiation levels at the tour, five and six foot elevations were greatly increased by the rod exercise. The combined average radiation level at the upper three feet of the rod drive mechanisms was increased from $117 \mathrm{mr} / \mathrm{hr}$ to $211 \mathrm{mr} / \mathrm{hr}$ which is an $80 \%$. increase.

The effects of the rod exercise on the radiation levels at the refueling ports and the FMI enclosures was not pronounced. The radiation levels at the top of the refueling ports and the top and middle of the FMI enclosures decreased. The radiation levels at the bottom of the FMI enclosures, and the middle and bottom of the refueling ports increased. The radiation levels of the .SMI bosses increased by $15 \%$ to $30 \%$ over the radiation levels which existed prior to the rod exercise.: The radiation level at the by-pass line on the mulitport valve increased from $425 \mathrm{mr} / \mathrm{hr}$, to $500 \mathrm{mr} / \mathrm{hr}$, but at the top of the valve body the radiation level dropped from $185 \mathrm{mr} / \mathrm{hr}$ : to $65 \mathrm{mr} / \mathrm{hr}$.

A calibration check of the two Cutie Ple survey meters was not made after this survey; however, the change in sensitivity of the meters during the survey was not more than $5 \%$ as indicated by the data obtained to check the effects of temperature on their sensitivity. (See Table VII)

Summary

The radiation surveys of the reactor vessel head that were performed before and after DLCS 14804, Control Rod Exercise Test indicates that two ful1 rod travel.cycles followed by two scrams from 69 inches is effective in reducing the radiation level around the rod drive mechanisms. The data in Table. III for the twentieth and twenty third performances of this test indicates that the combined average radiation levels of the lower three feet of the mechanisms were reduced approximately $35 \%$. to $40 \%$ from the averages which existed in that area prior to the rod exercise. The average radiation level at the one foot elevation for these two performances were reduced by almost $50 \%$. The performance of DLCS 14804 which decreases : the radiation levels at the. lower elevations also has the effect of increasing the radiation levels at the upper elevations. 
The increase in the radiation levels at the upper elevations which accompanies the lowering of radiation levels at the lower elevations indicates that the crud being dislodged at the lower elevations is apparently being re-distributed in the upper elevations. This re-distribution, if it is taking place, is of a temporary nature since the radiation levels of the upper elevations of the rod mechanisms decrease between performances of the test unless DLCS 14804 is performed.

Normal rod motion, that motion which is incurred by a rod group in controlling the reactor while it is at power, does not appear to effect the radiation levels of the rod drive mechanisms associated with the controlling rod group. During the period of time that the Group II control rods were used to control the reactor, their combined average radiation levels (See Table IV) for the lower three feet of the mechanisms varied from $0 \%$ to $76 \%$ above the combined average determined for all of the mechanisms. The combined average radiation levels for the upper elevations varied by $-3 \%$ to $+7 \%$ from the combined average radiation levels of all of the mechanisms. Later in Seed 3 life the Group II control rods were not used to control the reactor and the average radiation levels at the lower elevations of the Group II rod drive mechanisms varied from $0 \%$ to $+5 \%$ over the average radiation levels of all of the mechanisms. During this period, at the upper elevations, the combined average radiation levels of the Group II rod drive mechanisms varied $-3 \%$ to $+7 \%$ from the average radiation levels of all of the mechanisms.

The combined average radiation levels at the lower elevations of the rod drive mechanisms for the Group IV control rods varied $-8 \%$ to $+19 \%$ from the combined average radiation levels of all of the mechanisms when the Group IV control rods were not being used to control the reactor. When the Group IV control rods were used to contikol.the reactor their combined average radiation levels at the lower. elevations varied $+7 \%$ to $+8 \%$ above the average radiation levels of all the mechanisms. Also at this time, the combined average radiation levels at the upper elevations varied from the average radiation levels of all the mechanisms by $-4 \%$ to $+2 \%$ while the variation from the average of all the mechanisms for these upper elevations was $-30 \%$ to $+39 \%$ when they were not being used to control the reactor. Thus, neither the Group II. nor Group IV control rod drive mechanisms radiation levelı̈ exhibited a trend which would infer the radiation levels near the control rod drive mechanisms were dependent on whether or not they were being used to control the reactor.

The radiation levels of the refueling ports, the FMI enclosures and the multiport valve do not appear to have followed any definite trend to increase or decrease throughout seed 31 ife. The radiation levels of the SMI bosses appear to have increased, with some fluctuations during Seed 3. The average radiation level at the top of the refueling ports was $182 \mathrm{mr} / \mathrm{hr}$ at the end of Seed 3 life while the average radiation level at the top of the refueling ports was $239 \mathrm{mr} / \mathrm{hr}$ during DLCS 3050117 which occurred early in. Seed 3 life. The average radiation levels at the top and middle of the FMI enclosures decreased from $132 \mathrm{mr} / \mathrm{hr}$ and 207 $\mathrm{mr} / \mathrm{hr}$ to $123 \mathrm{mr} / \mathrm{hr}$ and $173 \mathrm{mr} / \mathrm{hr}$ respectively during. Seed 3 . All the other locations, the refueling ports and the FMI enclosures had an increase in radiation 


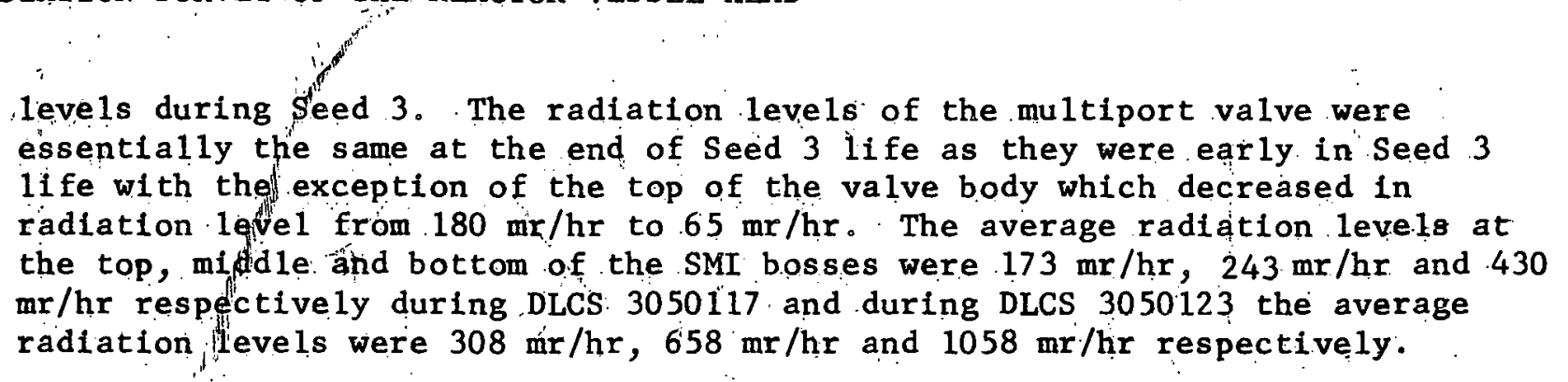

The effects of the crud concentration of the reactor coolant on the radiation levels (crud bufld-up) of the rod drive mechanisms is not definite. The average crud concentration in the reactor coolant preceding the two performances of this test which had high radiation levels at the lower elevations. (DLCS 3050119 and 22 ) was in excess of $4 \mathrm{ppb}$. The average crud concentration in the reactor coolant preceding DLCS 3050121 was only $2.76 \mathrm{ppb}$ and the radiation leve1s at the lower elevations were relatively low and had increased by $25 \%$ or less in approximately $1500 \mathrm{EFPH}$ of operation. In contrast the radiation levels during .DLCS 3050122 had increased by $50 \%$ at the one foot elevation in on $1 y 400$ EFPH of operation. Part of this increase may have been due to the crud from the upper areas of the mechanism dislodging and settling down to the lower elevations. The increase in radiation leve 1 s between DLCS 3050118 and 19 were on 1 y. $25 \%$ at the one foot elevation but at the two foot elevation the increase was over $40 \%$. The reactor had operated slightly over 2000 EFPH between the two test..performances. Thus, with the limited amount of data avallable, it would appear that high average crud levels in the reactor coolant result in high radiation levels at the lower elevations of the rod drive mechanisms.

The change in sensitivity of the Cutie Pie survey meter caused by changes in the temperature of the meter appears to be largely a function of the individual meter. In those instances where a certain meter was used during two performances of this test, the sensitivity of the meter either increased both times or decreased both times as 1 ts temperature increased. Cutie Pie survey meter No. 4100 war used during DLCS 3050119 and 20 and in both test performances the.sensitivity decreased as the temperature increased. Cutie Pie survey meter No. 4094 was used during. DLCS 3050117 and 19 and in both test performances it indlcated higher radiation levels as its temperature increased. Since a serieg of radlatton readings were not taken as the temperature was increasing it is not possible to state whether or not the change in sensitivity with increasing temperatures is a linear function. 
DUQUESNE LIGHT.. COMPANY POWER STATIONS DEPARTMENT

SHIPPINGPORT ATOMIC : POWER STATION
RADIATION. SURVEY OF. THE

REACTOR VESSEL . HEAD

DLCS $3050117-3050123$

\section{LIST OF TABLES}

Tạble:I Scrams, Thermal. Cycles and Crud Levels Preceding Head Surveys

Table II, Contro1. Rod Motion. During Seed 3

Table III Average Radiation Levels of Rod Drive Mechanisms

Table IV Average Radiation Levels of Group II and Group III Rod Drive Mechanísms

Table :V

Average Radiation Levels of Reactor Vessel Head Components

Table VI

Radiation Levels of the Multiport Valve

Table VII

Survey Meter Temperature: Sensitivity Data

Table VIII

Calibration Data for. Survey Meters 


\section{TABLE I}

Scrams, Thermal Cycles and Crud Levels Preceding Head Surveys

1. Seed 3 initial criticality - october 23, 1961

Average coolant crud levels preceding DLCS $3050117-3.05 \mathrm{ppb}$

(Avğ: of 16 samples)

* Cruid bursts preceding DLCS 3050117 - 20.5 ppb $(10 / 23 / 61-10 / 30 / 61)$

$16.6 \mathrm{ppb}(10 / 30 / 61-11 / 6 / 61)$ :

** Thërmal cycles precëding DLCS 3050117 - Nöne

Scrams preceding DLCS 3050117 -

(a) October 20 to 22, 1961 - A11 rods scrammed from 69 inches Pressure $1800 \mathrm{psig}$ Tavg 500 : F

(b) . February 18, 1962

- Scrammed with Group I rods at 69 inches and Group II rods at 1.5 inches. Pressure 1800 psig Tavg $500 \cdot \mathrm{F}$

(c) $\operatorname{March} 12,1962$

- Scrammed with Group I rods at 69 inches and Group. II rods at 50 inches Pressure 1800 psig Tavg $500 \cdot \mathrm{F}$

(d) $\operatorname{March} 13,1962$

- Scrammed with Group I and II rods' at 69 inches and Group III rods at 32.0 inches Pressure 1800 psig Tavg 500 . F

2. DLCS 3050117 performed Märch 14, 1,962 (3274. EFPH Core 1, Seed 3) Averagè coolant crud levels preceding DLCS 3050118 - No samples obtained Crud bursts preceding DLCS 3050118 - No samples obtained

* A crud burst is defined as any level of $10 \mathrm{ppb}$ or greater.

* A thermal cycle is defined as any change :in Tavg of $25 \mathrm{~F}$ or greater. 
DUQUESNE LIGHT .COMPANY POWER STATTONS DEPARTMENT

SHIPPINGPORT ATOMIC POWER STATION
RADIATION SURVEY OF THE REACTOR. VESSEL :HEAD DLCS 3050117 - 3050123

TABLE I (cont'd)

Therma1 cycles preceding DLCS 3050118 -

(a) March 16, 1962 - Tavg lowered to 425 F for 5 hours. Plant heated to $520 . \mathrm{F}$ and later to $536 \mathrm{~F}$.

(b) March 18, 1962 - Tavg lowered below $200 \cdot \mathrm{F}$

(c) March 31, 1962 - Tavig raised to $500 \mathrm{~F}$

(d) Apri1 1, 1962 - Tavg lowered to $300 . \mathrm{F}$ then raised to $500 \mathrm{~F}$

Scrams preceding DLCS 3050118"-

(a) March 14 and 15, 1962 - A11 rods scrammed from 69 inches Pressure 1800 psig Tavg $500 \mathrm{~F}$

(b) Apri1 4, 1962

- Scrammed with Group I röds at 69 inches and Group II rods at 63 inches Preceure 1800 psig Táy $500 \mathrm{~F}$

(c) Apri1 8, 1962

-. Scrammed with Group I rods at 69 inches and Group II' rods at 37.0 inchès Pressure 1800 psig Tavg 500 F

3. DLCS 3050118 performed April 14, 1962 (3429 EFPH Core 1, Seed 3) Average coolant crud levels preceding DLCS $3050119 \quad 4.02 \mathrm{ppb}$ (Avg。 of 13 sampless)

Crud bursts preceding DLCS 3050119 - 10.9 ppb (4/9/62 - 4/16/62) $19.7 \mathrm{ppb}(4 / 16 / 62-4 / 23 / 62)$

Thermà 1 cycles preçeding, DLCS 3050119: :

(a) May 20, 1962 - Tavg lowerëd to 250.F, then raised to $500 \cdot \mathrm{F}$ Scrams preceding DLCS 3050119 -

(a) April 17, 1962 - Scrammed with Group I rods at 69 inches and Group II rods at 49.0 inches Pressure 1760 psig Tavg 500 F 
DUQUESNE .LIGHT ..COMPANY POWER STATIONS DEPARTMENT

SHIPPINGPORT ATOMIC POWER. STATION
RADIATION SURVEY OF THE REACTOR VESSEL : HEAD DLCS 3050117 - 3050123

TABLE I (cont 'd)

(b) Mạy 1, 1962 - Scrammed with Group I rods at 69 inches and Group II rods at 55.0 inches Pressure 1780 psig Tavg $495 \mathrm{~F}$

(c) May 19, 1962 - All rods scrammed from 69. inches Pressurë 1800 psìg Távg 500 F

4. DLC3 3050119 performed July 24, 1962 (5454 EFPH Core 1, Seed 3) Average coolant crud levels preceding DLCS 3050120 - Same as those preceding DLCS 3050119

Crud bursts preceding DLCS 3050120 - Same as those preceding DLCS 3050119

Thermal cycles preceding DLCS 3050120 - Same as those preceding DLCS 3050119 Scrams preceding DLCS 3050120 -

(a) July 25 and 26, 1962 A11 rods scrammed from 69 inches Pressure 1800 psig Tavg $500 \mathrm{~F}$

5. DLCS 3050120 performed July 26, 1962 (5454 EFPH, Core 1, Seed 3). Average coolant crud levels preceding DLCS $3050121-2.76 \mathrm{ppb}$ (Av̈g. ö́ 5 samples)

Crud bursts preçeding DLCS 30050121 - None

Thermal cycles preceding DLCS 305̦0121 - None

Scrams preceding DLCS 3050121 - None

6. DLCS 3050121 performed September 27, 1962 (6935 EFPH, Core.1, Seed 3) Averáge coolant crud leve1s preceding DLCS $3050122-4.3 \mathrm{ppb}$

(Avg. of 8 samples)

Crud bursts preceding DLCS 3050122 - 54.3.ppb (10/16/62 - 10/17/62)

Thermal cycles preceding DLCS 3050122

(a) September 28, 1962 Tavg lowered to below $200 \cdot \mathrm{F}$ then increased Tavg to $500 \mathrm{~F}$ on 0ctober 17,1962 
TABLE. I (cont 'd)

Scrams preceding. DLCS 3050122

(a) September 28, 1962 - A11 rods scrammed from 69 inchẹs Pressure $1800^{\circ} \mathrm{psig}$ Tavg $500 \mathrm{~F}$

7. DLCS 3050122 performed November 23, 1962 (7329 EFPH, Core 1, Seed 3) Average coolant crud levels preceding DLCS 3050123 - Same as'preceding DLCS 3050122

Crud bursts preceding. DLCS 3050123 - Same as preceding DLC' 3050122

Thermal cycles preceding DLCS 3050123 - Same as preceding DLCS 3050122

Scrams preceding DLCS 3050123 -

(ä) Novembér 24, 1962 - All rods scrammed from 69 inches Pressure 1800 psig Tavg 475.F

8. DLCS 3050123 performed November.24, 1962 (7329.EFPH, Core 1, Seed 3) 
DUQUESNE LIGHT COMPANY

POWER STATIONS DEPARTMENT

SHIPPINGPORT ATOMIC POWER STATION
RADIAT-ON SURVEY OF THE REACTOR VESSEL HEAD

DLCS 3050117 through DLCS 3050123

TABLE II

Control Rod Motior. During Seed 3

\begin{tabular}{|c|c|c|c|c|c|c|c|c|c|c|c|c|c|}
\hline $\begin{array}{l}\text { Control Rod } \\
\text { Sub-Group }\end{array}$ & $\begin{array}{c}\text { Rod Motion Between } \\
\text { Beginning of Seed } 3 \\
\text { and DLCS } 3050117 \\
\text { feet }\end{array}$ & $\begin{array}{l}\text { Rod MotLon Between } \\
\text { DLCS } 3050117 \text { and } \\
\text { DLCS } 3050118 \\
\text { feet } \\
\end{array}$ & $\begin{array}{l}\text { Rod Motion Between } \\
\text { DLCS } 3050118 \text { and } \\
\text { DLCS } 3050119 \\
\text { feet } \\
\end{array}$ & $\begin{array}{l}\text { Rod S } \\
\text { DLCS } \\
\text { DLCS } \\
\end{array}$ & $\begin{array}{l}\text { Motion Between } \\
3050119 \text { and } \\
3050120 \\
\text { feet }\end{array}$ & $\begin{array}{l}\text { Rod M } \\
\text { DLCS } \\
\text { DLCS } \\
\end{array}$ & $\begin{array}{l}\text { Motion Between } \\
3050120 \text { and } \\
3050121 \\
\text { feet }\end{array}$ & $\begin{array}{l}\text { Rod M } \\
\text { DLCS } \\
\text { DLCS } \\
\end{array}$ & $\begin{array}{l}\text { Motlon Bet } \\
3050121 \\
3050122 \\
\text { feet } \\
\end{array}$ & $\begin{array}{l}\text { etween } \\
\text { and }\end{array}$ & $\begin{array}{l}\text { Rod } 1 \\
\text { DLCS } \\
\text { DLCS }\end{array}$ & $\begin{array}{l}\text { Motion Bet } \\
3050122 \\
3050123 \\
\text { feet }\end{array}$ & $\begin{array}{l}\text { etween } \\
\text { and }\end{array}$ \\
\hline 1 's & 88 & 223 & 252 & & 36 & & 12 & & 39 & & & 36 & \\
\hline 2 's & 353 & 230 & 291 & & 36 & & 12 & & 39 & & & 36 & \\
\hline 3's & 97 & 223 & 252 & & 36 & & 12 & & 39 & & & 36 & \\
\hline $4 \mathrm{~s}$ & 38 & 43 & 292 & & 36 & & 61 & & 47.5 & & & 36 & \\
\hline 518 & 93 & 223 & 252 & & 36 & & 12 & & 39. & . & & 36 & \\
\hline $6 \mathrm{~s}$ & 378 & 185 & 297 & & 36 & & 12 & & 39 & & & 36 & \\
\hline $7 \mathrm{~s}$ & 88 & 223 & 252 & & 36 & & 12 & & 39 & & & 36 & \\
\hline 8 's & 17 & 6 & 270 & & 36 & & 34 & , & 111 & & & 36 & \\
\hline
\end{tabular}




\section{TABLE III}

Average Radiation Levels of Rod Drive Mechanisms

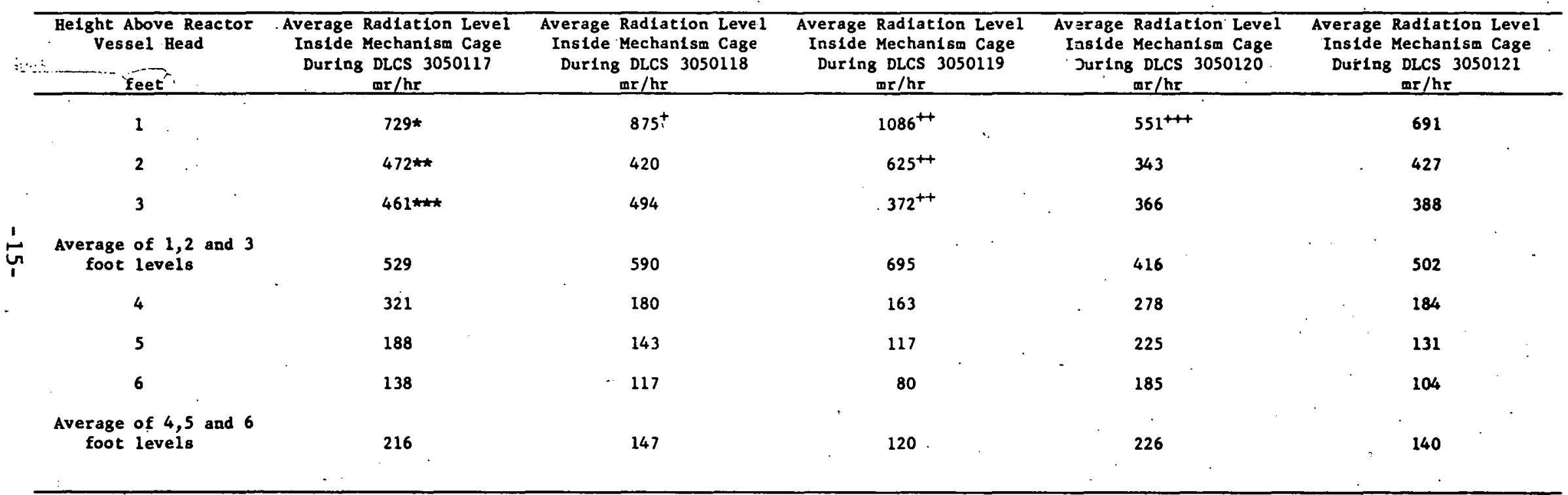

* Mechanisms D-11, E-11, E-12, F-12, G-12, H-12, I-12, L-9, L-6, L-5, K-5, K-4, J-4, I-4 and H-4 not included 1n average

* MechenLsms E-12, F-12, G-12, H-12, I-12, R-4 and $\mathrm{J}-4$ not included In average

*t Mechanisms E-12, F-12 and $R-4$ not Included In average

+ Mechanlsms D-10 and D-11 not included In average

+ Mechanisms $J-12, K-12, K-11, L-11, L-10, L-9, L-8$ and L-7 not included in averages

++ Mechanisms D-10, D-11 and $L-5$ not lacluded In averages 
DUQUESNE LIGHT COMPANY

POHER STATIONS DEPARTMENT

SHIPPINGPORT ATOMIC POWER STATION
RADLATION SURVEY OF THE REACTOR VESSEL READ DLCS 3050117 through DLCS 3050123

TABLE IlI (cont'd)

Average Radiation Levels of Rod Drive Mechanisms

\begin{tabular}{|c|c|c|c|c|c|}
\hline & $\begin{array}{c}\text { Height Above } \\
\text { Reactor Vessel } \\
\text { Head } \\
\text { feet }\end{array}$ & $\begin{array}{c}\text { Average Radiation Level } \\
\text { Inside Mechanisr Cage } \\
\text { During DLCS } 3050122 \\
\mathrm{mr} / \mathrm{hr} \\
\end{array}$ & $\begin{array}{r}\text { Average } \\
\text { Instde } \\
\text { During }\end{array}$ & $\begin{array}{l}\text { Radiation } \\
\text { Mechaniso } \\
8 \text { DLCS } 3050 \\
\mathrm{mr} / \mathrm{hr}\end{array}$ & $\begin{array}{l}\text { Level } \\
\text { Cage } \\
0123\end{array}$ \\
\hline & 1 & 1044 & & 544 & \\
\hline & 2 & 406 & & 309 & \\
\hline & 3 & 341 & , & 283 & \\
\hline & $\begin{array}{c}\text { Average of } 1,2 \text { and } 3 \\
\text { foot levels }\end{array}$ & 597 & & 379 & \\
\hline . & 4 & 150 & & 255 & . \\
\hline & 5 & 115 & & 204 & . \\
\hline & 6 & 87 & & 174 & \\
\hline & $\begin{array}{l}\text { Average of } 4,5 \text { and } 6 \\
\text { foot levels }\end{array}$ & 117 & & 211 & . \\
\hline
\end{tabular}


DUQUESNE LIGTT COMPANY

POWER STATIONS DEPARTMERT

SHIPPINGPORT ATOMIC POWER STATION
RADIATION SURVEY OF THE REACTOR VESSEL HEAD. DLCS 3050117 through DLCS 3050123

TABLE IV

Average Radiation Levels of Group II and Group IV Control Rod $D=1$ ve Mechanisms

\begin{tabular}{|c|c|c|c|c|c|c|c|c|c|c|c|c|c|c|}
\hline $\begin{array}{c}\text { Helght Above Reactor } \\
\text { Vessel Head } \\
\text { feet }\end{array}$ & \multicolumn{2}{|c|}{$\begin{array}{c}\text { Average Radiatlon } \\
\text { Level Ins1de Mech- } \\
\text { an1sm Cage During } \\
\text { DLCS } 3050117 \\
\text { mr/hr } \\
\end{array}$} & \multicolumn{2}{|c|}{$\begin{array}{c}\text { Average Radiation } \\
\text { Level Inside Mech- } \\
\text { antsm Cage During } \\
\text { DLCS } 3050118 \\
\text { mr/hr }\end{array}$} & \multicolumn{2}{|c|}{$\begin{array}{c}\text { Average Radiation } \\
\text { Level Ins1de Mech- } \\
\text { an1sm Cage During } \\
\text { DLCs } 3050119 \\
\text { mr } / \mathrm{hr} \\
\end{array}$} & \multicolumn{2}{|c|}{$\begin{array}{c}\text { Average Radiation } \\
\text { Level Inside Mech- } \\
\text { an1sm Cage. During } \\
\text { DLCS } 3050120 \\
\mathrm{mr} / \mathrm{hr} \\
\end{array}$} & \multicolumn{2}{|c|}{$\begin{array}{c}\text { Average Radiation } \\
\text { Level Inside Mech- } \\
\text { anism Cage During } \\
\text { DLCS } 3050121 \\
\mathrm{mr} / \mathrm{hr} \\
\end{array}$} & \multicolumn{2}{|c|}{$\begin{array}{c}\text { Average Radiation } \\
\text { Level Inside Mech- } \\
\text { anism Cage During } \\
\text { DLCS } 3050122 \\
\mathrm{mr} / \mathrm{hr} \\
\end{array}$} & \multicolumn{2}{|c|}{$\begin{array}{c}\text { Average Radiation } \\
\text { Level Inside Mech- } \\
\text { anlsm Cage During } \\
\text {, DLCS } 3050123 \\
\mathrm{mr} / \mathrm{hr} \\
\end{array}$} \\
\hline & $\begin{array}{c}\text { Group } \\
\text { II }\end{array}$ & $\begin{array}{c}\text { Group } \\
\text { IV }\end{array}$ & $\begin{array}{c}\text { Group } \\
\text { II }\end{array}$ & $\begin{array}{l}\text { Group } \\
\text { IV }\end{array}$ & $\begin{array}{c}\text { Group } \\
\text { II }\end{array}$ & $\begin{array}{c}\text { Group } \\
\text { IV }\end{array}$ & $\begin{array}{c}\text { Group } \\
\text { II }\end{array}$ & $\begin{array}{c}\text { Group } \\
\text { IV }\end{array}$ & $\begin{array}{c}\text { Group } \\
\text { II }\end{array}$ & $\begin{array}{c}\text { Group } \\
\text { IV }\end{array}$ & $\begin{array}{c}\text { Group } \\
\text { II }\end{array}$ & $\begin{array}{c}\text { Group } \\
\text { IV }\end{array}$ & $\begin{array}{c}\text { Group } \\
\text { II }\end{array}$ & $\begin{array}{l}\text { Group } \\
\text { IV }\end{array}$ \\
\hline 1 & 740. & 850 & 929 & 800 & 1113 & ${ }_{1} 5^{41150}$ & 561 & 613 & 669 & 800 & 1056 & 1100 & .538 & 613 \\
\hline 2 & 507 & 504 & 398 & 513 & 668 & 550 & 344 & 356 & 438 & 425 & 394 & 450 & 328 & 338 \\
\hline 3 & 480 & 529 & 491 & 450 & 383 & 350 & 366. & 331 & 394 & 400 & 363 & 375 & 297 & 269 \\
\hline $\begin{array}{l}\text { Average of } 1,2 \text { and } \\
3 \text { foot levels }\end{array}$ & 561 & 628 & 591 & 545 & 728 & 683 & 424 & 433 & 500 & 542 & 604 & 642 & 388 & 407 \\
\hline 4 & 334 & 186 & 178 & 303 & 165 & 163 & 288 & 219 & 186 & 180 & 156 & 160 & 263 & 250 \\
\hline 5 & 188 & 148 & 136 & 183 & 103 & 115 & 241 & 231 & 129 & 125 & 117 & 116 & 213 & 200 \\
\hline 6 & 139 & 120 & $113^{\circ}$ & 130 & 81 & 78 & 194 & 188 & 108 & 98 & 88 & 84 & 178 & 181 \\
\hline $\begin{array}{c}\text { Average of } 4,5 \text { and } \\
6 \text { foot levels }\end{array}$ & 220 & 151 & 142 & 205 & 116 & 119 & 241 & 213 & 141 & 134 & 120 & 120 & 218 & 210 \\
\hline
\end{tabular}

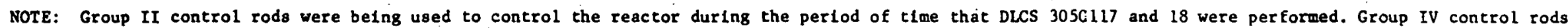
were belag used to control the reactor during the period of time the DLCS 3050121,22 and 23 were performed. 
DUQUESNE IIGET COAPANY

POWER STATIONS DEPARTYEATT

SHIPPINGPORT ATOKIC POWER STATION
RADIATION SURVEY OF THE REACTOR VESSEL HEAD

DLCS 30.50117 through DLCS 3050123

TABLE V

Average Radiation Levels of Reactor Vessel Head Components

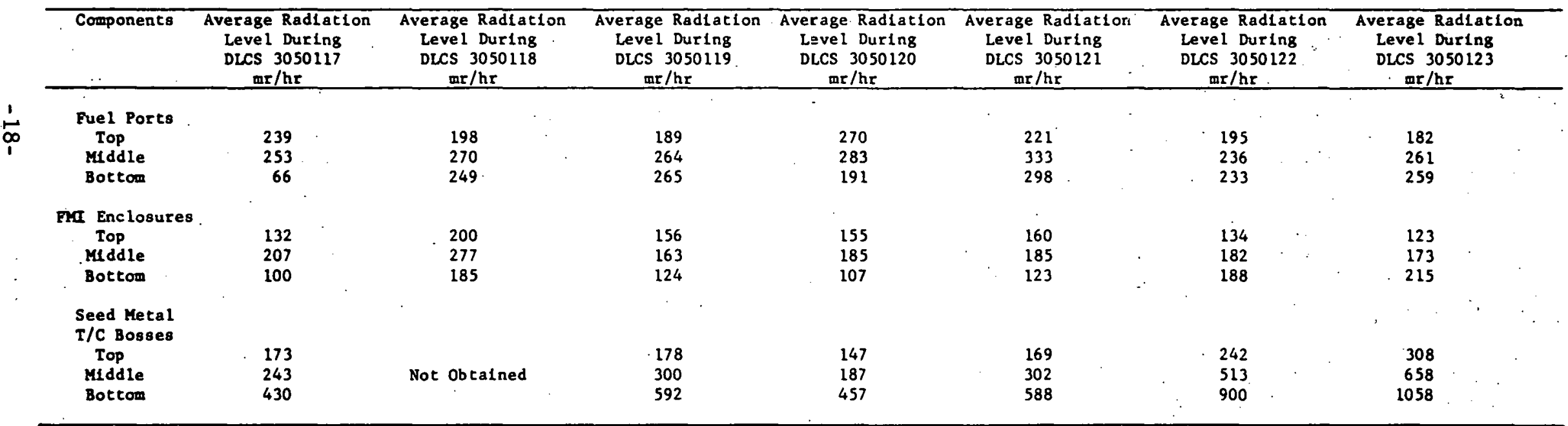


DUQUESNE LIGET COKPANY

POWER STATIONS DEPARTMENT

SHIPPINGPORT ATOMIC POWER STATION
RADIATION SURVEY OF THE REACTOR VESSEL HEAD

DLCS 3050117 through DLCS 3050123

\section{TABL.E VI}

Radlation Levels of the Multiport Valve

\begin{tabular}{|c|c|c|c|c|c|c|c|c|c|c|c|c|c|c|c|c|c|}
\hline Survey Point Location & $\begin{array}{l}\text { Rad1a } \\
\text { During }\end{array}$ & $\begin{array}{l}\text { Dtion Level } \\
\text { DLCS } 3050117 \\
\mathrm{mr} / \mathrm{hr}\end{array}$ & $\begin{array}{c}\text { Radia } \\
\text { During } \\
\end{array}$ & $\begin{array}{l}\text { ation Level } \\
\mathrm{DLCS} 3050118 \\
\mathrm{mr} / \mathrm{hr}\end{array}$ & $\begin{array}{r}\text { Radla } \\
\text { During } \\
\end{array}$ & $\begin{array}{l}\text { aclon Level } \\
\mathrm{DLCS} 305 \mathrm{C} 119 \\
\mathrm{mr} / \mathrm{hr}\end{array}$ & $\begin{array}{r}\text { Rad1a } \\
\text { During }\end{array}$ & $\begin{array}{l}\text { ation } \\
\text { DLCS } \\
\mathrm{mr} / \mathrm{hr} \\
\end{array}$ & $\begin{array}{l}\text { Level } \\
3050120 \\
r\end{array}$ & $\begin{array}{c}\text { Radta } \\
\text { During } \\
\end{array}$ & $\begin{array}{l}a=10 n \\
\text { JLCS } \\
\mathrm{ar} / \mathrm{hr}\end{array}$ & $\begin{array}{l}\text { Level } \\
3050121\end{array}$ & $\begin{array}{r}\text { Radia } \\
\text { During } \\
\end{array}$ & $\begin{array}{l}\text { acton } \\
\text { DLCS } \\
\text { ar/hr }\end{array}$ & $\begin{array}{l}\text { Level } \\
3050122 \\
\end{array}$ & $\begin{array}{r}\text { Radtation } \\
\text { During DLCS } \\
\mathrm{ar} / \mathrm{hr} \\
\end{array}$ & $\begin{array}{l}\text { Leve1 } \\
3050123\end{array}$ \\
\hline $\begin{array}{l}\text { Contact, side of } \\
\text { stator water jacket } \\
\text { at top }\end{array}$ & & 80 & & 110 & & 60 & & .500 & & & 52 & & & 60 & . & 80 & $\cdot$ \\
\hline $\begin{array}{l}\text { Contact, top of } \\
\text { valie body }\end{array}$ & . & 180 & & 450 & & 105 & & 275 & & & $\check{100}$ & & & 185 & & 65 & 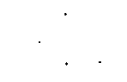 \\
\hline $\begin{array}{l}\text { Contacting insulation } \\
\text { on valive body directly } \\
\text { beneatb by-pass line }\end{array}$ & . & 460 & & 600 & & 450 & & 375 & & & 680 & & & 425 & & 500 & $\therefore$ \\
\hline $\begin{array}{l}\text { Contacting insulation } \\
\text { on valve body at bottom } \\
\text { above instrument port } \\
\text { collar }\end{array}$ & & 370 & & 275 &. & 400 & & 420 & . & . & 500 & & & 350 & . & 350 & \\
\hline
\end{tabular}


DUQUESNE LIGHT COMPANY

POWER STATIONS DEPARTMENT

SBIPPINGPORT ATOMIC POWER STATION
RADIATION SURVEY OR THE REACTOR VESSEL BRAD DLCS 3050117 through DLCS 3050123

TABLE VII

Survey Meter Temperature Sensitivity Data

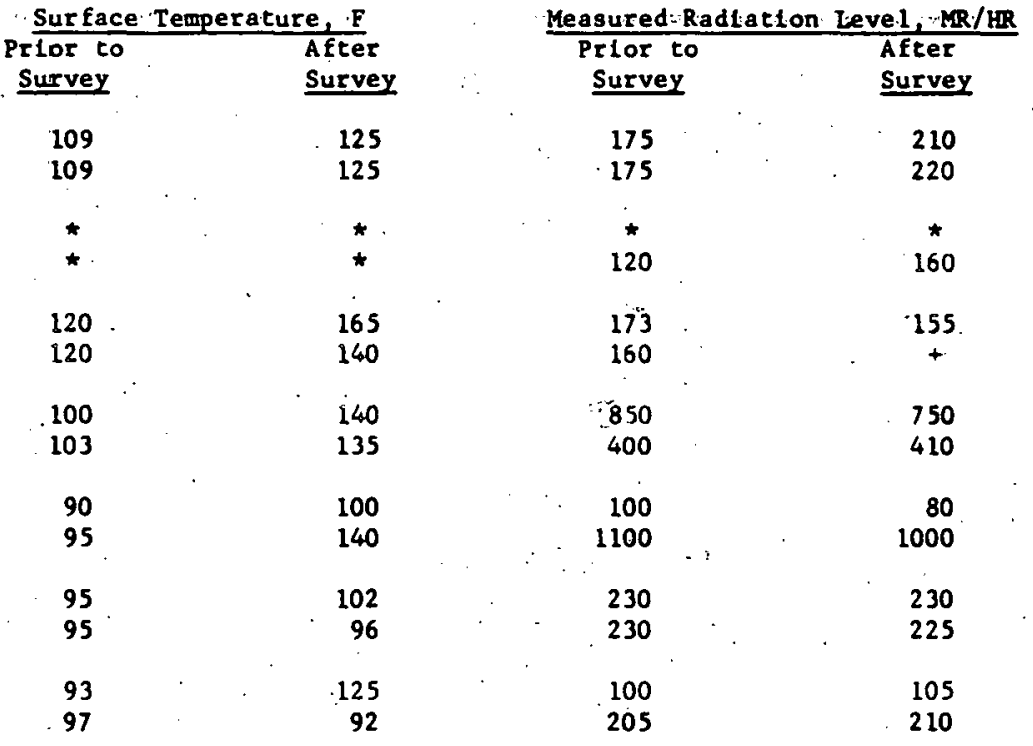

- Data not obtalned.

+ Meter falled. Read 700 MR/HR Ia a 450 MR/HR radiation field. 
DUQUESNE LIGHY COMPANY

POWER STATIONS DEPARTMENT

SHIPPINGPORT ATOMLC POWER STATION
RADLATION SURVEY OF THE REACTOR VESSEI GEAD DLCS 3050117 through DLCS .3050123

TABLE VIII

Calibration Data for Survey Mecers

DLCS 3050117 Performed March 14, 1962

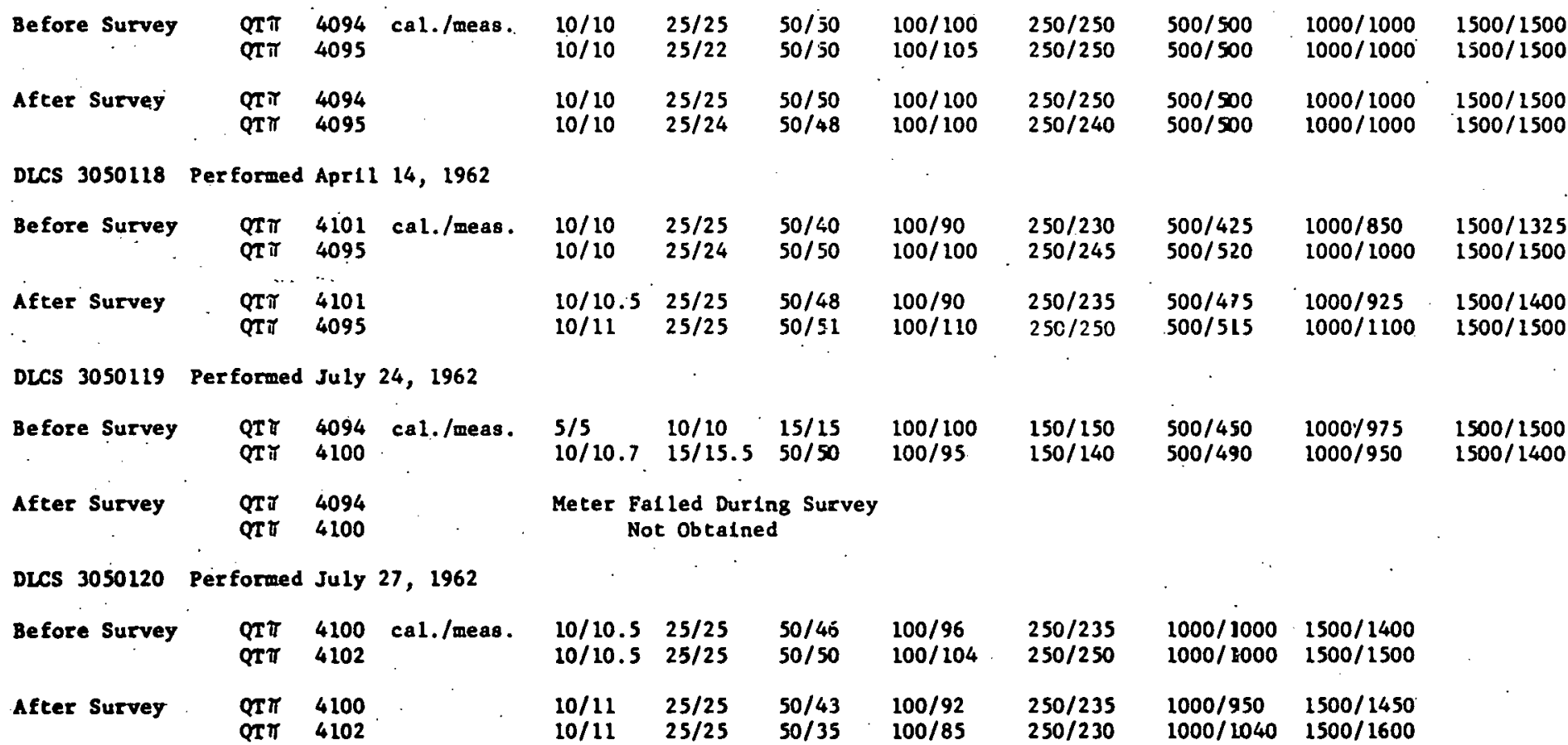


DUQUESNE LIGRT COMPANY

POWER STATIONS DEPARTMEATI

SAIPPINGPORT ATOMIC POWER STATION
RADIATION SURVEY OF THE REACTOR VESSEL HEAD DLCS 3050117 through DLCS 3050123

\section{TABLE VIII}

(cont'd)

DLCS 3050121 Performed September 27, 1962

$\begin{array}{lll}\text { QTT } & 3438 & \text { cal./meas. } \\ \text { QT } & 4093\end{array}$

$10 / 10 \quad 15 / 15$

$25 / 25 \quad 50 / 53 \quad 25 / 25 \quad 50 / 50$

$100 / 100 \quad 250 / 205$

$10 / 9.5 \quad 15 / 15.5 \quad 25 / 25 \quad 50 / 48$

$25 / 23$

$50 / 51$

\begin{tabular}{ll} 
QT & 3438 \\
\hline$\pi$ & 4093
\end{tabular}

$50 / 48$

$100 / 100$

$1000 / 1000 \quad 1500 / 1500$

$100 / 92$

$250 / 2 \div 2$.

$500 / 490$

$1000 / 950$

$1000 / 950$

$1500 / 1650$

DLCs 3050122 Performed November 23, 1962

$\begin{array}{llll}\text { Before Survey } & \text { QT } \pi & 3438 & \text { cal./meas. } \\ & \text { OT } \pi & 4099\end{array}$

After Survey

QTi 3438 .

$10 / 10$

$10 / 10$

$15 / 15$

$.50 / 50$

$100 / 100$

-

$150 / 150$

$150 / 150$
$150 / 150$

$500 / 500$

$500 / 500$

$1000 / 1000$

$1000 / 1000$

$1000 / 1000$

$1500 / 1500$

$10 / 10$. $15 / 15$

$50 / 50 \cdots 100 / 100$

$150 / 150$

Not Obtained

DLCS 3050123 Performed November 24, 1962

Before Survey.

QT 3438 cal./meas.

QT 4099.

$10 / 10$

$15 / 15$

$50 / 45$

$100 / 95$

$100 / 100$

$150 / 145$

$150 / 150$

$500 / 450$

$500 / 450$

$1000 / 1000$

$1000 / 950$

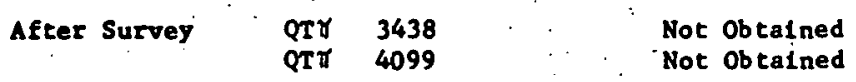

$\begin{array}{lllll}\text { After Survey } & \text { QT } & 3438 & & \text { Not Obtained } \\ & \text { QTT } & 4099 & \cdots & \text { Not Obtained }\end{array}$ 
TEST PROCEDURE DECS 3050117 through DLCS 3050123

RADIATION SURVEY OF THE REACTOR VESSEL HEAD

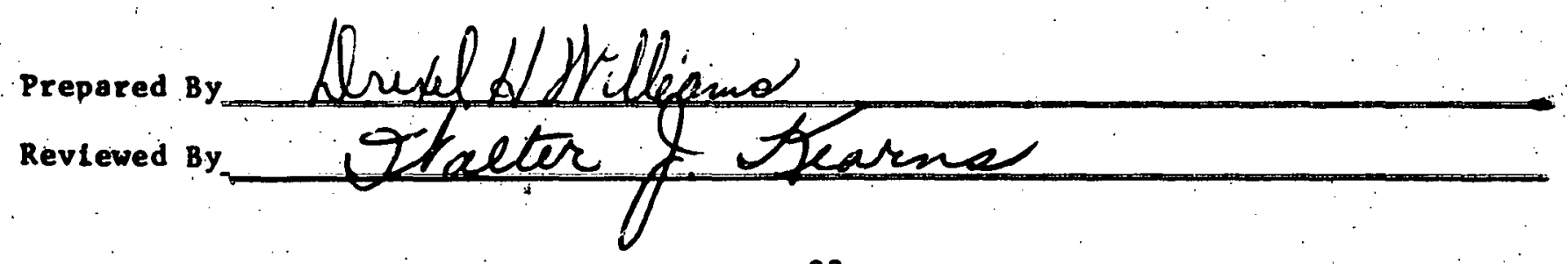

$-23-$ 